\title{
Implementation of The Quantum Learning Model to Improve Critical Thinking Skills Students of Elementary School
}

\section{Riky Rivaldi Pratama}

\author{
Universitas Sebelas Maret
}

riky.teacher@gmail.com

\section{Article History}

received 30/4/2021

\begin{abstract}
Critical thinking skills are essential skills for 21st-century life. Critical thinking skills are closely related to the ability to understand the complex world with its various problem. The purpose of this research was to improve critical thinking skills using Quantum. This type of research is classroom action research with the implementation of three cycles and each cycle consists of two meetings. Each consists of four steps there were planning, action, observation, and reflection cycles. The data was collected by using several techniques such as observation, interview, documentation, and critical thinking test. The interactive model was used to analyze the data. The assessment of research showed that both students' critical thinking increased continuously. Based on the results, it can be concluded that trough quantum models based on experiments enhancing the student's critical thinking skills of heat and transfer for grade $V$ students.
\end{abstract}

Keywords: Critical Thinking, Quantum, Elementary school

\begin{abstract}
Abstrak
Keterampilan berpikir kritis adalah keterampilan penting untuk kehidupan abad ke-21. Keterampilan berpikir kritis berkaitan erat dengan kemampuan memahami dunia yang kompleks dengan berbagai permasalahannya. Tujuan dari penelitian ini adalah untuk meningkatkan kemampuan berpikir kritis dengan menggunakan Quantum. Jenis penelitian ini adalah penelitian tindakan kelas dengan pelaksanaan tiga siklus dan setiap siklus terdiri dari dua pertemuan. Masing-masing terdiri dari empat langkah yaitu siklus perencanaan, tindakan, observasi, dan refleksi. Pengumpulan data dilakukan dengan menggunakan beberapa teknik seperti observasi, wawancara, dokumentasi, dan tes berpikir kritis. Model interaktif digunakan untuk menganalisis data. Hasil penilaian penelitian menunjukkan bahwa kemampuan berpikir kritis kedua peserta didik terus meningkat. Berdasarkan hasil penelitian dapat disimpulkan bahwa melalui model kuantum berbasis eksperimen meningkatkan kemampuan berpikir kritis peserta didik tentang kalor dan perpindahan pada peserta didik kelas V.
\end{abstract}

Kata kunci: Berpikir Kritis, Quantum, Sekolah Dasar 


\section{PENDAHULUAN}

Pendidikan saat ini dihadapkan pada tantangan kehidupan abad ke- 21 . Keterampilan yang harus dimiliki di abad ke-21 meliputi : (1) keterampilan berpikir kritis dan pemecahan masalah; (2) keterampilan berkomunikasi dan bekerjasama; (3) keterampilan berpikir kreatif dan memperbaharui; (4) literasi teknologi dan bekerjasama; (5) keterampilan belajar kontekstual; (6) kemampuan informasi dan literasi media (Ciğerci, 2020). Berpikir kritis adalah berpikir untuk menafsirkan, menganalisis, mengevaluasi, menyimpulkan, menjelaskan, dan meregulasi (Facione, 2011; Grant \& Smith, 2018; Palavan, 2020). Berpikir kritis merupakan tingkat berpikir golongan atas atau termasuk berpikir tingkat tinggi karena membutuhkan analisis dan evaluasi dalam menghadapi suatu kasus (Tosuncuoglu, 2018; Bayram et al., 2019; Polat, 2020). Keterampilan berpikir kritis bukan hanya tentang peserta didik mampu memahami konsep, mengahafal materi, namun juga bagaimana peserta didik mampu menganalisis suatu konsep dan permasalahan (Özelçi \& Çalışkan, 2019; Erdoğan, 2020; Evans, 2020).

Bukti empiris yang diperoleh dari pengamatan keterampilan berpikir kritis melalui indikator yang telah ditentukan sebelumnya menunjukkan bahwa keterampilan berpikir kritis peserta didik masih tergolong rendah. Hal tersebut diperoleh dari hasil pretest yang telah dilakukan hanya $18,18 \%$ ( 2 peserta didik) yang masuk kategori cukup kritis, sedangkan $81,81 \%$ (9 peserta didik) masuk kategori kurang kritis dari jumlah total peserta didik 11 peserta didik.

Berdasarkan hasil wawancara, quesioner dan observasi penyebab rendahnya keterampilan berpikir kritis peserta didik SDN Kayen 3 yaitu proses pembelajaran yang diterapkan guru biasanya kurang mengarah pada keterampilan berpikir kompleks yang salah satu bagiannya adalah berpikir kritis. Peserta didik kurang terbiasa belajar dengan tujuan untuk berpikir kritis. Rendahnya keterampilan berpikir kritis ini jika tidak segera diatasi akan menimbulkan dampak buruk. Peserta didik akan kesulitan beradaptasi dengan perkembangan zaman yang semakin maju. Peserta didik menjadi kurang mampu memecahkan masalah dalam kehidupan sehari- hari. Kualitas peserta didik sebagai generasi muda akan kalah bersaing dengan negara lain, yang mengakibatkan kurang optimalnya pemanfaatan sumber daya di Indonesia.

Permasalahan yang ditemukan dalam wawancara dan observasi merupakan hambatan dalam menunjang keterampilan berpikir kritis peserta didik. Maka diperlukan suatu model pembelajaran inovatif yang dapat meningkatkan keterampilan berpikir kritis. Model pembelajaran diterapkan dapat memberikan stimulus terhadap peserta didik untuk menganalisis dan menilai suatu masalah. Salah satu model pembelajaran yang dapat meningkatkan keterampilan berpikir kritis adalah model pembelajaran Quantum. Model Pembelajaran Quantum merupakan model yang dapat memberikan stimulus kepada peserta didik agar lebih kritis dalam menghadapi persoalan-persoalan di kehidupan sehari-hari (Zeybek, 2017; Afacan \& Gürel, 2019).

Model pembelajaran Quantum Learning merupakan model pembelajaran yang membiasakan belajar menyenangkan. Penerapan model ini diharapkan dapat meningkatkan minat belajar peserta didik sehingga pada akhirnya peserta didik dapat meningkatkan hasil belajar secara menyeluruh. Model pembelajaran Quantum Learning adalah gabungan yang sangat seimbang antara bekerja dan bermain, antara rangsangan internal dan eksternal dan waktu yang dihabiskan di dalam zona aman dan akan melangkah keluar dari tempat asal atau kebiasaan lama (Gunarhadi et al., 2014; Altın \& Saracaloğlu, 2019). Setiap model pembelajaran memiliki sintaks sebagai pedoman untuk implementasi kedalam pembelajaran di kelas. Sintaks dalam suatu model diadaptasi dari berbagai model yang pernah ada dan dimodifikasi agar relevan terhadap variabel yang hendak ditingkatkan. Model pembelajaran Quantum memiliki sintaks yaitu : (1) Tumbuhkan; (2) Amati; (3) Namai; (4) Demonstrasi; (5) Ulangi; (6) Rayakan (Zeybek, 2017; Kristiyanto et al., 2020). Tumbuhkan berarti pada awal 
kegiatan pembelajaran guru wajib menumbuhkan/mengembangkan minat peserta didik untuk belajar. Dengan tumbuhnya minat, peserta didik paham manfaat kegiatan pembelajaran bagi diri dan kehidupannya. Alami mengandung makna bahwa proses pembelajaran akan lebih bermakna jika peserta didik mengalami secara langsung atau nyata materi yang diajarkan. Sebagai inovasi, tahap ini bisa dilakukan dengan menampilkan video yang menarik. Namai mengandung makna bahwa waktunya untuk mengajarkan konsep, keterampilan berpikir, dan strategi belajar. Pada tahap ini juga kegiatan diskusi berlangsung untuk menyelesaikan tantangan. Demonstrasikan berarti bahwa memberi kesempatan kepada peserta didik untuk mempresentasikan pengetahuannya ke dalam diskusi atau ke dalam kehidupan peserta didik. Kegiatan ini akan dapat menigkatkan hasil belajar peserta didik. Ulangi berarti bahwa proses pengulangan dalam kegiatan pembelajaran dapat memperkuat koneksi intelektual dan menumbuhkan rasa yakin terhadap kemampuan peserta didik. Pada tahap ulangi, guru memberikan suatu konfirmasi terhadap hasil demonstrasi peserta didik untuk memperbaiki kesalahan-kesalahan konsep. Rayakan mengandung makna pemberian penghargaan kepada peserta didik atas usaha, ketekunan, dan kesuksesannya dalam menyelesaikan setiap tantangan yang diberikan oleh guru. Dapat didefinisikan juga sebagai umpan balik positif kepada peserta didik atas keberhasilannya, baik berupa pujian, pemberian hadiah, atau bentuk lainnya. Diharapkan dengan adanya penghargaan peserta didik semangat untuk belajar.

Berdasarkan hasil penelitian, maka tujuan penelitian ini meningkatkan keterampilan berpikir kritis peserta didik kelas V SD Negeri 3 Kayen. Manfaat penggunaan model pembelajaran Quantum untuk menstimulus keterampilan berpikir kritis peserta didik agar meningkat. Penelitian ini dapat dijadikan referensi bagi peneliti lain terkait upaya dalam meningkatkan keterampilan berpikir kritis.

\section{METODE}

Penelitian ini dilakukan pada peserta didik kelas V SD Negeri 3 Kayen, Boyolali tahun ajaran 2020/2021. Penelitian dilakukan selama 6 bulan, yaitu dari Januari 2021 sampai Juni 2021. Jenis Penelitian yang digunakan adalah Penelitian Tindakan Kelas (PTK). Penelitian dilakukan dalam tiga siklus,masing-masing siklus terdiri dari dua pertemuan. Data yang digunakan dalam penelitian ini adalah data kualitatif dan data kuantitatif. Data kualitatif berupa hasil observasi, wawancara, serta dokumentasi. Data kuantitatif dalampenelitian ini berupa hasil tes keterampilan berpikir kritis peserta didik. Teknik pengumpulan data dalam penelitian ini yaitu observasi, wawancara, tes keterampilan berpikir kreatif dan dokumentasi. Hasil tes keterampilan berpikir kritis digunakann untuk mengkategorikan peserta didik berdasarkan tingkat kritisnya. Peserta didik dikategorikan kritis jika mencapai skor lebih dari 75, kategori cukup kritis jika memperoleh skor dari 51 sampai 75, kategori kurang kritis jika memperoleh skor 26 samapi 50, dan kategori tidak kritis jika memperoleh skor 25 kebawah. Validitas data yang digunakan dalam penelitian ini yaitu validitas isi. Data dianalisis dengan analisis analisis interaktif Miles-Huberman melalui empat tahapan yaitu pengumpulan data, reduksi data, penyajian data, dan penyimpulan/verifikasi data.

\section{HASIL DAN PEMBAHASAN}

Setelah Tindakan penelitian dilaksanakan, maka langkah selanjutnya adalah menganalisis hasil penelitian. Hasil pada kegiatan pra siklus hingga siklus 3 di ukur untuk diketahui seberapa berhasil penelitian yang dilakukan. Hasil tes pada pratindakan menunjukkan bahwa sebagian besar peserta didik belum masuk kategori kreatif. Rincian mengenai hasil uji pratindakan keterampilan berpikir kreatif peserta didik adalah sebagai berikut: 
Tabel 1. Data nilai Keterampilan Berpikir Kritis Pratindakan

\begin{tabular}{|c|c|c|c|}
\hline Kategori & Interval & $\begin{array}{c}\text { Jumlah Peserta } \\
\text { didik }\end{array}$ & Presentase \\
\hline Tidak Kritis & $\leq 25$ & 0 & $0 \%$ \\
\hline Kurang Kritis & $26-50$ & 9 & $81,81 \%$ \\
\hline Cukup Kritis & $51-75$ & 2 & $18,18 \%$ \\
\hline Kritis & $>75$ & 0 & $0 \%$ \\
\hline \multicolumn{2}{|c|}{ Jumlah } & 11 & $100 \%$ \\
\hline
\end{tabular}

Berpijak dari data di atas, dapat diketahui bahwa persentase peserta didik yang masuk kategori tidak kritis tes pratindakan keterampilan berpikir kritis $0 \%$ atau sebanyak 0 peserta didik, persentase kategori kurang kritis $81,81 \%$ atau sebanyak 9 peserta didik. Persentase kategori cukup kritis yaitu $18,18 \%$ atau sebanyak 2 peserta didik. Persentase kritis yaitu $0 \%$ atau sebanyak 0 peserta didik. Setelah implementasi model pembelajaran Quantum, keterampilan berpikir kreatif peserta didik kelas V SD Negeri 3 Kayen mengalami peningkatan dari pratindakan. Hasil tes keterampilan berpikir kreatif pada siklus I dijabarkan dalam tabel berikut ini:

Tabel 2. Data nilai Keterampilan Berpikir Kritis Siklus 1

\begin{tabular}{cccc}
\hline Kategori & Interval & $\begin{array}{c}\text { Jumlah } \\
\text { Peserta didik }\end{array}$ & Persentase \\
\hline Tidak Kritis & $\leq 25$ & 0 & $0 \%$ \\
Kurang Kritis & $26-50$ & 4 & $36,36 \%$ \\
Cukup Kritis & $51-75$ & 4 & $36,36 \%$ \\
Kritis & $>75$ & 3 & $27,27 \%$ \\
\hline Jumlah & & 11 & $100 \%$ \\
\hline
\end{tabular}

Tabel 2 menunjukkan bahwa keterampilan berpikir kreatif peserta didik di akhir siklus 1 mengalami kenaikan dibandingkan pada pratindakan. Persentase peserta didik yang masuk kategori tidak kritis tes pratindakan keterampilan berpikir kritis $0 \%$ atau sebanyak 0 peserta didik, persentase kategori kurang kritis $36,36 \%$ atau sebanyak 4 peserta didik. Persentase kategori cukup kritis yaitu 36,36\% atau sebanyak 4 peserta didik. Persentase kritis yaitu $27,27 \%$ atau sebanyak 3 peserta didik. Kenaikan pada rata-rata nilai dan ketuntasan klasikal belum mencapai atau memenuhi indikator kinerja penelitian yang telah ditetapkan sehingga dilanjutkan ke siklus II. Hasil tes keterampilan berpikir kreatif siklus II dijabarkan dalam tabel berikut ini :

Tabel 3. Data nilai Keterampilan Berpikir Kritis Siklus 2

\begin{tabular}{cccc}
\hline Kategori & Interval & $\begin{array}{c}\text { Jumlah } \\
\text { Peserta didik }\end{array}$ & Persentase \\
\hline Tidak Kritis & $\leq 25$ & 0 & $0 \%$ \\
Kurang Kritis & $26-50$ & 2 & $18,18 \%$ \\
Cukup Kritis & $51-75$ & 3 & $27,27 \%$ \\
Kritis & $>75$ & 6 & $54,54 \%$ \\
\hline Jumlah & & 11 & $100 \%$ \\
\hline
\end{tabular}


Berdasarkan paparan data dari Tabel 3 keterampilan berpikir kreatif peserta didik di akhir siklus 2 mengalami kenaikan dibandingkan pada siklus 1 . Persentase peserta didik yang masuk kategori tidak kritis tes pratindakan keterampilan berpikir kritis $0 \%$ atau sebanyak 0 peserta didik, Persentase kategori kurang kritis $18,18 \%$ atau sebanyak 2 peserta didik. Persentase kategori cukup kritis yaitu 27,27\% atau sebanyak 3 peserta didik. Persentase kritis yaitu 54,54\% atau sebanyak 6 peserta didik. Kenaikan pada rata-rata nilai dan ketuntasan klasikal belum mencapai atau memenuhi indikator kinerja. Indikator kinerja penelitian belum tercapai sehingga dilajutkan ke siklus berikutnya. Paparan mengenai hasil siklus III adalah sebagai berikut :

Tabel 4. Data nilai Keterampilan Berpikir Kritis Siklus 3

\begin{tabular}{cccc}
\hline Kategori & Interval & $\begin{array}{c}\text { Jumlah } \\
\text { Peserta didik }\end{array}$ & Persentase \\
\hline Tidak Kritis & $\leq 25$ & 0 & $0 \%$ \\
Kurang Kritis & $26-50$ & 0 & $0 \%$ \\
Cukup Kritis & $51-75$ & 1 & $9,09 \%$ \\
Kritis & $>75$ & 10 & $90,90, \%$ \\
\hline Jumlah & & 11 & $100 \%$ \\
\hline
\end{tabular}

Paparan data pada Tabel 4 menunjukkan bahwa Persentase peserta didik yang masuk kategori tidak kritis tes pratindakan keterampilan berpikir kritis $0 \%$ atau sebanyak 0 peserta didik, Persentase kategori kurang kritis $0 \%$ atau sebanyak 0 peserta didik. Persentase kategori cukup kritis yaitu 9,09\% atau sebanyak 1 peserta didik. Persentase kritis yaitu $90,90 \%$ atau sebanyak 10 peserta didik. Pada siklus III, tindakan dihentikan karena ketuntasan klasikal sudah lebih dari $90 \%$, yaitu sejumlah 10 peserta didik mendapat kriteria kreatif (90,90\%). Pembelajaran pada siklus III sudah berhasil dan indikator kinerja penelitian telah tercapai dengan tidak ada kendala yang berarti. Pada kondisi ini penelitian dihentikan karena sudah mencapai target.

Berdasarkan tindakan siklus I hingga siklus III, menunjukkan bahwa model pembelajaran Quantum dapat meningkatkan keterampilan berpikir kritis peserta didik SD Negeri 3 Kayen. Model pembelajaran Quantum dapat memberdayakan dan meningkatkan keterampilan berpikir kritis. Peningkatan keterampilan berpikir kritis dapat dilakukan dengan memfasilitasi belajar peserta didik untuk mengembangkan daya kritisnya, memberikan kesempatan untuk berpikir, mendorong peserta didik untuk mengekspresikan penilaiannya terhadap sesuatu, dan membuka kesempatan untuk memperoleh insight baru (Bayram et al., 2019; Özelçi \& Çalışkan, 2019). Hal tersebut dapat di optimalkan dengan model pembelajaran Quantum. Sejalan dengan penelitian dari Dwi et al., (2016) bahwa model pembelajaran quantum dapat meningkatkan keterampilan berpikir kritis peserta didik.

\section{SIMPULAN}

Berdasarkan uraian hasil penelitian, dapat disimpulkan bahwa implementasi model pembelajaran Quantum dapat meningkatkan keterampilan berpikir kritis peserta didik kelas V SD Negeri 3 Kayen tahun ajaran 2020/2021. Hal ini dibuktikan melalui data yang menunjukkan peningkatan keterampilan berpikir kreatif setiap siklus. Pesentase keterampilan berpikir kreatif pada pratindakan sebesar $0 \%$. Pesentase pada siklus I sebesar 27,27\%, siklus II sebesar 54,54\%, sedangkan siklus III sebesar $90,09 \%$. Hasil penelitian ini memberikan implikasi teoritis sebagai pengetahuan, 
wawasan, serta sumber rujukan bagi penelitian sejenis. Penelitian ini juga memberikan implikasi praktis bagi proses pembelajaran berupa peningkatan keterampilan berpikir kritis setelah implementasi model Quantum.

\section{DAFTAR PUSTAKA}

Afacan, Ö., \& Gürel, İ. (2019). The Effect of Quantum Learning Model on Science Teacher Candidates' Self-Efficacy and Communication Skills. Journal of Education and Training Studies, 7(4), 86. https://doi.org/10.11114/jets.v7i4.4026

Altın, M., \& Saracaloğlu, A. S. (2019). The effect of Quantum learning model on foreign language speaking skills, speaking anxiety and self-efficacy of secondary school students. Journal of Language and Linguistic Studies, 15(3), 1083-1104. https://doi.org/10.17263/jlls.631550

Bayram, D., Kurt, G., \& Atay, D. (2019). The implementation of webquest-supported critical thinking instruction in pre-service english teacher education: The Turkish context. Participatory Educational Research, 6(2), 144-157. https://doi.org/10.17275/per.19.18.6.2

Ciğerci, F. M. (2020). Primary School Teacher Candidates and 21st Century Skills. International Journal of Progressive Education, 16(2), 157-174. https://doi.org/10.29329/ijpe.2020.241.11

Dwi, D., Wenda, N., Ahdhianto, E., Aka, A., \& Keguruan, F. (2016). Model Pembelajaran Ipa Berbasis Quantum. 2(1), 110-122.

Erdoğan, F. (2020). The relationship between prospective middle school mathematics teachers' critical thinking skills and reflective thinking skills. Participatory Educational Research, 7(1), 220-241. https://doi.org/10.17275/per.20.13.7.1

Evans, C. (2020). Measuring student success skills: A review of the literature on selfdirected learning. Center For Assessment, 1-18. www.nciea.org

Facione, P. a. (2011). Critical Thinking: What It Is and Why It Counts. In Insight assessment (Issue ISBN 13: 978-1-891557-07-1.). https://www.insightassessment.com/CT-Resources/Teaching-For-and-AboutCritical-Thinking/Critical-Thinking-What-It-Is-and-Why-It-Counts/Critical-ThinkingWhat-It-ls-and-Why-It-Counts-PDF

Grant, M., \& Smith, M. (2018). Quantifying Assessment Of Undergraduate Critical Thinking. Journal of College Teaching \& Learning (TLC), 15(1), 27-38. https://doi.org/10.19030/tlc.v15i1.10199

Gunarhadi, Kassim, M., \& Shaari, A. S. (2014). The impact of quantum teaching strategy on student academic achievements and selfesteem in inclusive schools. Malaysian Journal of Learning and Instruction, 11(1), 191-205. https://doi.org/10.32890/mjli.11.2014.7671

Kristiyanto, W., Gunarhadi, \& Indriayu, M. (2020). The Effect of the Science Technology Society and the Quantum Teaching Models on Learning Outcomes of Students in the Natural Science Course in Relation with Their Critical Thinking Skills. International Online Journal of Education and Teaching, 7(1), 177-191.

Özelçi, S. Y., \& Çalışkan, G. (2019). What is critical thinking? A longitudinal study with teacher candidates. International Journal of Evaluation and Research in Education, 8(3), 495-509. https://doi.org/10.11591/ijere.v8i3.20254

Palavan, Ö. (2020). The effect of critical thinking education on the critical thinking skills and the critical thinking dispositions of preservice teachers. Educational Research and Reviews, 15(10), 606-627. https://doi.org/10.5897/err2020.4035

Polat, S. (2020). Multidimensional Analysis of the Teaching Process of the Critical Thinking Skills. Research in Social Sciences and Technology, 5(2), 134-157. https://doi.org/10.46303/ressat.05.02.8

Tosuncuoglu, I. (2018). Place of critical thinking in EFL. International Journal of Higher 
Volume 9 Nomor 1 Tahun 2021

Education, 7(4), 26-32. https://doi.org/10.5430/ijhe.v7n4p26

Zeybek, G. (2017). An Investigation on Quantum Learning Model. International Journal of Modern Education Studies, 1(1), 16. https://doi.org/10.51383/ijonmes.2017.12 